\title{
Analysis Of Clinical And Demographic Characteristics For The Differential Diagnosis Of Pseudothrombocytopenia
}

\author{
Psödotrombositopeni Ayırıcı Tanısı İçin Klinik Ve Demografik Özelliklerin \\ Analizi
}

\author{
Abdulkerim Yıldız, Murat Albayrak, Osman Şahin, Hacer Berna Afacan Öztürk, Senem Maral \\ Sağlık Bilimleri Üniversitesi, Dışkapı Yıldırım Beyazıt Eğitim Ve Araştırma Hastanesi, Hematoloji Bölümü, \\ Ankara, Türkiye
}

Dergiye Ulaşma Tarihi: 07.11.2019 Dergiye Kabul Tarihi: 18.02.2020 Doi: 10.5505/aot.2020.92499

\begin{abstract}
ÖZET
GİRIŞ ve AMAÇ: EDTA'ya bağlı yalancı trombositopeni (EDTA-PTCP), otomatik kan sayımı analizörleri ile yapay düşük trombosit sayımlarına yol açan, in vitro bir trombosit kümelenmesi olgusudur. PTCP bilgisi, klinik değerlendirmenin doğruluğu ve gereksiz tedaviyi önlemek için önemlidir. Bu çalışmanın amacı, trombositopeni durumunda PTCP şüphesi için kullanılabilecek öngörücü belirleyicileri tespit etmektir.

YÖNTEM ve GEREÇLER: Ocak 2016-Ocak 2019 tarihleri arasında 3 yıllık süre boyunca hematoloji bölümümüze başvuran hastaların retrospektif bir değerlendirmesi yapıldı. PTCP ayırıcı tanısı için ayırt edici bir parametre belirlemek amacı ile PTCP hastaları ile immün trombositopeni (ITP) hastaları ve sağlıklı bireyler arasında karşılaştırmalar yapıldı. Demografik özellikler, hemogram ve biyokimyasal parametreler, altta yatan ve eşlik eden hastalıklar ve trombosit indeksler araştıııldı.

BULGULAR: EDTA-PTCP'li 164 hasta, ITP'li 43 hasta ve 45 sağlıklı kontrol hastasının değerlendirmesi yapıldı. PTCP hastalarında komorbidite sayısı, trombosit sayısı, ortalama trombosit hacmi, trombosit ve trombosit dağılım genişliği hem ITP hem de kontrol grubundan anlamlı olarak farklıydı $(p<0.05)$. Lojistik regresyon analizi, PTCP'yi ITP'den veya kontrol grubundan ayırt etmek için kullanılabilecek anlamlı bir parametre olmadığını gösterdi ( $>>0.05)$.

TARTIŞMA ve SONUÇ: PTCP'yi trombositopenik ve sağlıklı durumlardan ayırmak için hematolojik parametrelerin kullanımı düşünülebilir. Ancak, mikroskobik periferik kan yayma analizi hala en güvenilir ve ayırt edici yöntemdir.
\end{abstract}

Anahtar Kelimeler: psödotrombositopeni, tanı, kan parametreleri

\section{ABSTRACT}

INTRODUCTION: EDTA-dependent pseudothrombocytopenia (EDTA-PTCP) is an in-vitro phenomenon of platelet clumping that leads to artificial low platelet counts by automatic hematology analyzers. Knowledge of PTCP is important for the accuracy of a clinical assessment and to avoid unnecessary treatment. The aim of this study was to determine easily available predictive markers which can be used for suspicion of PTCP in case of thrombocytopenia.

METHODS: A retrospective evaluation was made of patients admitted or referred to our hematology department during the 3-year period from January 2016 to January 2019. Comparisons were made of the PTCP patients with immune thrombocytopenia (ITP) and healthy subjects to determine a distinctive parameter for the differentiation of PTCP. Differences were investigated in demographic characteristics, hemogram and biochemical parameters, underlying and comorbid diseases and platelet indices.

RESULTS: Evaluation was made of 164 patients with EDTA-PTCP, 43 patients with ITP and 45 healthy control subjects. In PTCP patients, the number of comorbidities, platelet count, mean platelet volume, plateletcrit and platelet distribution width were significantly different from both the ITP and control groups $(p<0.05)$. Logistic regression analysis revealed no significant parameter that could be used to differentiate PTCP either from ITP or the control group ( $\mathrm{p}>0.05)$.

DISCUSSION AND CONCLUSION: Hematological parameters may be considered for the use to differentiate PTCP from thrombocytopenic and healthy conditions. However, microscopic peripheral blood smear analysis is still the most reliable and distinctive method.

Keywords: pseudothrombocytopenia, diagnosis, blood parameters 


\section{Introduction}

Ethylenediaminetetraacetic acid (EDTA) dependent pseudothrombocytopenia (PTCP) is a common laboratory phenomenon with prevalence of $0.07 \%-2 \%$ (1-4). EDTA-PTCP was first reported by Gowland et al. in 1969 (5). It is caused by in vitro platelet (Plt) clumping, which leads to spuriously low Plt counts by automatic hematology analyzers. As a result of incorrect measurements, PTCP may cause diagnostic failure although it has no clinical significance. Manual examination of a peripheral blood (PB) smear showing platelet clumps in a patient with no bleeding history should raise suspicion about this in vitro phenomenon.

The mechanism has not been clearly defined. It is considered to be an anticoagulant-dependent immunologically-mediated phenomenon due to the presence of anti-Plt autoantibodies $(6,7)$. Glycoprotein IIb is present as a $\mathrm{Ca}^{+2}$-dependent heterodimer complexed with glycoprotein IIIa. The epitope of the antiplatelet antibody causing EDTA-PTCP is a cryptoantigen that is only revealed in the dissociated form of glycoprotein IIb. The dissociation of the dimer is dependent on calcium concentration. Therefore, EDTA has calcium chelating effect that induces the antigen antibody binding (8-10).

Knowledge of PTCP is important for the accuracy of a clinical assessment and to avoid unnecessary treatment. This phenomenon, if unrecognized, can lead to additional testing, delays in diagnostic or therapeutic procedures, and inappropriate treatments including platelet transfusion, steroid therapy, and splenectomy. There are a limited number of studies evaluating PTCP and risk factors and associated underlying diseases. Therefore, it is important to identify and reliably correct spurious low platelet counts in a timely manner to avoid the unnecessary treatment of healthy individuals or selected patient populations. The aim of this study was to determine the incidence and associated parameters of EDTA-PTCP, and to determine distinctive markers that could be used at the time of admission when PTCP is suspected in cases of thrombocytopenia.
A retrospective evaluation was made of all patients who were admitted, referred or consulted to our hematology department during the 3-year period from January 2016 to January 2019. Complete blood count (CBC) was performed using blood anticoagulated with $5 \%$ sodium EDTA. PB smear is routinely prepared for all patients admitted to our department as an institutional protocol. The patients with thrombocytopenia were analyzed and 3 groups were formed;

1. Patients with EDTA-PTCP

2. Patients with newly-diagnosed immune thrombocytopenia (ITP) (control 1)

3. Healthy subjects (control 2)

EDTA-PTCP was diagnosed from the following criteria (2) : 1) reduction of the platelet count to $\left.<100 \times 10^{9} / \mathrm{L} ; 2\right)$ presence of platelet agglutinates in EDTA-anticoagulated samples; confirmed presence of platelet clumps by microscopic examination of PB smears stained with Wright's \& Giemsa stains.

Patients with any hematological malignancy or hematology-associated disease were excluded. A control group of newly-diagnosed ITP patients was selected from the same database, as they had real thrombocytopenia with the exclusion of other disease causing thrombocytopenia. The other control group was formed of healthy subjects who were admitted to the hematology department with normal CBC and biochemical laboratory tests and without any underlying disease. The PTCP patients were compared with ITP patients and the healthy subjects to assess distinctive parameters for PTCP. Differences were investigated in demographic characteristics, CBC and biochemical parameters, underlying and comorbid diseases and platelet indices. It was aimed to determine easily available predictive markers which could be used when PTCP is suspected in cases of thrombocytopenia.

\section{Statistical analysis}

Data obtained in the study were analysed statistically using SPSS 24 software. KruskalWallis $\mathrm{H}$ test statistics were used to compare 3 or more independent variables with the measured values. $\chi 2$-cross tables were used to investigate the relationship between two categorical variables. The relative risk (RR) was calculated according to this table. The Binary Logistic regression method was used to analyze

\section{Materials and methods}


risk situations. A value of $\mathrm{p}<0.05$ was accepted as statistically significant.

\section{Ethical approval and informed consent}

All procedures performed in studies involving human participants were in accordance with the ethical standards of the institutional and/or national research committee and with the 1964 Helsinki Declaration and its later amendments or comparable ethical standards. As a standard of care/action of our hospital, the patient records confirmed that all the study patients gave informed consent at the time of hospitalization and before the administration of any intervention.

\section{Results}

Evaluation was made of 164 patients with EDTA-PTCP, 43 patients with ITP and 45 healthy control subjects. The patients with EDTA-PTCP comprised 62 males $(37.8 \%)$ and 102 females $(62.2 \%)$, with a median age of 52.0 years (range: 18.0-94.0 years). The median platelet count was $54.5 \times 10^{3} / \mu \mathrm{L}$ (range: 1.0 99.0) in the presence of EDTA. The demographic characteristics and blood parameters of the 3 groups are shown in Table 1.

Of the PTCP cases, 92.6\% $(n=152)$ were outpatients, and the others were hospitalized. In 65 PTCP patients (39.6\%), 118 comorbidities were determined. The most common diseases were hypertension (HT) (n:19, 16.1\%), Diabetes Mellitus (DM) (n:18, 15.2\%), Hypohyperthyroidism (n:17, 14.4\%), cardiovascular disease (n:12, 10.1\%) and solid organ malignancies (n:9, 7.6\%). In 36 patients $(22.0 \%)$ at least one autoimmune-associated disease was determined.

To determine distinctive parameters to differentiate PTCP, the PTCP group was compared with the ITP and control groups. In the PTCP group, the number of comorbidies, Plt count, Mean platelet volume (MPV) level, Plateletcrit (Pct) and Platelet distribution width (Pdw) were significantly different from both the ITP and control groups $(p<0.05)$. The comparisons of the 3 groups are shown in Table 1. Logistic regression analysis revealed no significant association (Table $\mathbf{2}$ and $\mathbf{3}$ ).

Table 1. Demographic characteristics and blood parameters of the groups 


\begin{tabular}{|c|c|c|c|c|}
\hline & $\begin{array}{l}\operatorname{PTCP}^{(1)} \\
(n=164)\end{array}$ & $\begin{array}{l}\text { ITP }{ }^{(2)} \\
(n=43)\end{array}$ & $\begin{array}{c}\text { Control }^{(3)} \\
(n=45)\end{array}$ & $p$ \\
\hline $\begin{array}{l}\text { Age, years, median [min.- } \\
\text { max.] }\end{array}$ & $52.0[18.0-94.0]$ & $48.0[20.0-77.0]$ & $41.0[22.0-72.0]$ & 0.265 \\
\hline $\begin{array}{l}\text { Gender } \\
\text { Female }(\mathrm{n}, \%) \\
\text { Male }(\mathrm{n}, \%)\end{array}$ & $\begin{array}{l}102(\% 62.2) \\
62(\% 37.8)\end{array}$ & $\begin{array}{l}28(\% 65.1) \\
15(\% 34.9)\end{array}$ & $\begin{array}{l}30(\% 66.7) \\
15(\% 33.3)\end{array}$ & 0.834 \\
\hline Number of comorbidies & $1.5[0.0-5.0]$ & $1.0[0.0-2.0]$ & $0.0[0.0-0.0]$ & 0.000 \\
\hline $\begin{array}{l}\text { Otoimmune disease } \\
\text { Yes } \\
\text { No }\end{array}$ & $\begin{array}{l}36(\% 22.0) \\
128(\% 78.0)\end{array}$ & $\begin{array}{l}6(\% 14.0) \\
37(\% 86.0)\end{array}$ & $-\overline{4}(\% 100.0)$ & 0.002 \\
\hline $\begin{array}{l}\text { Wbc }\left(\times 10^{3} / \mathrm{mm}^{3}\right) \text { median } \\
{[\text { min.-max.] }}\end{array}$ & $8.1[1.6-28.6]$ & $7.9[4.3-18.0]$ & $7.0[4.7-11.6]$ & 0.095 \\
\hline $\begin{array}{l}\text { Hb }(\mathrm{g} / \mathrm{dL}) \text { median [min.- } \\
\text { max.] }\end{array}$ & $13.5[6.3-16.9]$ & $13.5[7.7-17.6]$ & $13.8[11.9-16.6]$ & 0.208 \\
\hline $\begin{array}{l}\text { Plt }\left(\times 10^{3} / \mathrm{mm}^{3}\right) \text { median } \\
{[\text { min.-max.] }}\end{array}$ & $54.5[1.0-99.0]$ & $4.0[1.0-64.0]$ & $\begin{array}{l}256.0[159.0- \\
340.0]\end{array}$ & 0.000 \\
\hline $\begin{array}{l}\text { MPV (fL) median [min.- } \\
\text { max.] }\end{array}$ & $9.4[6.6-14.8]$ & $8.8[5.7-12.7]$ & $8.5[6.5-10.4]$ & 0.000 \\
\hline Pct $(\%)$ median [min.-max.] & $0.05[0.00-0.12]$ & $0.01[0.0-0.22]$ & $0.22[0.13-0.28]$ & 0.000 \\
\hline $\begin{array}{l}\text { Pdw (\%)median [min.- } \\
\text { max.] }\end{array}$ & $17.6[13.5-20.0]$ & $16.7[13.5-20.1]$ & $16.6[15.7-17.7]$ & 0.000 \\
\hline $\begin{array}{l}\text { Neutrophil }\left(\times 10^{3} / \mathrm{mm}^{3}\right) \\
\text { median [min.-max.] }\end{array}$ & $4.4[1.1-26.1]$ & $5.0[2.0-15.0]$ & $4.2[2.5-8.3]$ & 0.168 \\
\hline $\begin{array}{l}\text { Lymphocyte }\left(\times 10^{3} / \mathrm{mm}^{3}\right) \\
\text { median [min.-max.] }\end{array}$ & $2.2[0.3-6.9]$ & $1.9[0.6-3.9]$ & $2.1[1.3-3.6]$ & 0.144 \\
\hline $\begin{array}{l}\text { Monocyte }\left(\times 10^{3} / \mathrm{mm}^{3}\right) \\
\text { median [min.-max.] }\end{array}$ & $0.58[0.0-4.3]$ & $0.5[0.17-2.1]$ & $0.5[0.3-0.8]$ & 0.320 \\
\hline $\begin{array}{l}\text { Creatinine }(\mathrm{mg} / \mathrm{dL}) \text { median } \\
{[\text { min.-max.] }}\end{array}$ & $0.8[0.5-3.0]$ & $0.8[0.6-1.2]$ & $0.8[0.4-1.6]$ & 0.423 \\
\hline $\begin{array}{l}\text { Total bilirubine }(\mathrm{mg} / \mathrm{dL}) \\
\text { median [min.-max.] }\end{array}$ & $0.6[0.1-4.3]$ & $0.6[0.3-1.9]$ & $0.5[0.3-2.6]$ & 0.230 \\
\hline $\begin{array}{l}\text { AST (U/L) median [min.- } \\
\operatorname{max.]}\end{array}$ & $22.0[12.0-747.0]$ & $18.5[11.0-35.0]$ & $20.0[8.0-50.0]$ & 0.031 \\
\hline $\begin{array}{l}\text { ALT (U/L) median [min.- } \\
\operatorname{max.]}\end{array}$ & $17.5[6.0-303.0]$ & $17.0[9.0-34.0]$ & $17.0[6.0-94.0]$ & 0.942 \\
\hline $\begin{array}{l}\text { Calcium }(\mathrm{mg} / \mathrm{dL}) \text { median } \\
\text { [min.-max.] }\end{array}$ & $9.5[7.2-11.4]$ & $9.5[8.3-10.4]$ & $9.5[8.6-10.6]$ & 0.495 \\
\hline $\begin{array}{l}\text { Sodium }(\mathrm{mEq} / \mathrm{L}) \text { median } \\
{[\text { min.-max.] }}\end{array}$ & $138.0[127.0-144.0]$ & 139.0 [132.0-142.0] & $\begin{array}{l}140.0[136.0- \\
143.0]\end{array}$ & 0.009 \\
\hline $\begin{array}{l}\text { Potassium }(\mathrm{mEq} / \mathrm{L}) \text { median } \\
\text { [min.-max.] }\end{array}$ & $4.1[3.4-5.2]$ & $3.9[3.2-4.6]$ & $4.3[3.8-5.0]$ & 0.000 \\
\hline $\begin{array}{l}\text { LDH (U/L) median [min.- } \\
\text { max.] }\end{array}$ & $196.0[137.0-2200.0]$ & $215.0[133.0-433.0]$ & $\begin{array}{l}187.0[132.0- \\
248.0]\end{array}$ & 0.022 \\
\hline $\begin{array}{l}\text { Ferritin }(\mathrm{ng} / \mathrm{mL}) \text { median } \\
\text { [min.-max.] }\end{array}$ & $29.0[2.6-1500.0]$ & $31.0[2.4-313.0]$ & $17.5[1.1-323.0]$ & 0.301 \\
\hline $\begin{array}{l}\text { Vitamin B12 (pg/mL) } \\
\text { median [min.-max.] }\end{array}$ & $229.0[53.0-1500.0]$ & $172.0[26.0-1500.0]$ & $241.0[45.0-782.0]$ & 0.010 \\
\hline
\end{tabular}

PTCP: Pseudothrombocytopenia, ITP: Immune thrombocytopenia, WBC: White blood count, Hb: Hemoglobin, Plt: Platelet, MPV: Mean platelet volume, Pct: Plateletcrit, PDW: Platelet disturbution width, AST: Aspartate aminotransferase, AST: Alanine aminotransferase, LDH: Lactate dehydrogenase 
Table 2. Logistic regression analysis of parameters between PTCP and control group

\begin{tabular}{|c|c|c|c|c|c|c|c|c|}
\hline & \multirow[t]{2}{*}{ B } & \multirow[t]{2}{*}{ SE } & \multirow{2}{*}{$\begin{array}{c}\text { Wal } \\
\text { d }\end{array}$} & \multirow[t]{2}{*}{ df } & \multirow[t]{2}{*}{$p$} & \multirow[t]{2}{*}{$\operatorname{Exp}(B)$} & \multicolumn{2}{|c|}{$95 \%$ CI for $\operatorname{Exp}(B)$} \\
\hline & & & & & & & Lower & Upper \\
\hline Comorbidity & 1.559 & 4086.501 & .000 & 1 & 1.000 & 4.753 & .000 & 7.345 \\
\hline $\begin{array}{l}\text { Otoimmun } \\
\text { disease }\end{array}$ & -3.371 & 9988.773 & .000 & 1 & 1.000 & .034 & .000 & 0.058 \\
\hline Plt & .000 & .533 & .000 & 1 & .999 & 1.000 & .352 & 2.839 \\
\hline MPV & .475 & 6519.204 & .000 & 1 & 1.000 & 1.607 & .000 & 2.102 \\
\hline Pct & -31.812 & 588462.86 & .000 & 1 & 1.000 & .000 & .000 & 0.000 \\
\hline Pdw & 1.531 & 3287.321 & .000 & 1 & 1.000 & 4.624 & .000 & 5.824 \\
\hline Vit B12 & .001 & 8.565 & .000 & 1 & 1.000 & 1.001 & .000 & 1.045 \\
\hline Constant & 35.307 & 188.373 & .000 & 1 & 1.000 & 200.000 & & \\
\hline
\end{tabular}

PTCP: Pseudothrombocytopenia, Plt: Platelet, MPV: Mean platelet volume, Pct: Plateletcrit, PDW: Platelet disturbution width, B: Beta coefficient, CI: Confience interval, SE: Standard error, df: degree of freedom, Exp (B): exponentiation of B coefficient

Table 3. Logistic regression analysis of parameters between ITP and control group

\begin{tabular}{|c|c|c|c|c|c|c|c|c|}
\hline & \multirow[t]{2}{*}{$\mathbf{B}$} & \multirow[t]{2}{*}{ SE } & \multirow[t]{2}{*}{ Wald } & \multirow[t]{2}{*}{ df } & \multirow[t]{2}{*}{$p$} & \multirow[t]{2}{*}{$\operatorname{Exp}(B)$} & \multicolumn{2}{|c|}{$95 \%$ CI for $\operatorname{Exp}(B)$} \\
\hline & & & & & & & Lower & Upper \\
\hline Comorbidity & -5.993 & 39114.603 & .000 & 1 & 1.000 & .002 & .000 & 0.004 \\
\hline $\begin{array}{l}\text { Otoimmun } \\
\text { disease }\end{array}$ & 9.020 & 72607.978 & .000 & 1 & 1.000 & 8265.260 & .000 & 7.042 \\
\hline Plt & .000 & .256 & .000 & 1 & .999 & 1.000 & .605 & 1.653 \\
\hline MPV & .051 & 3586.316 & .000 & 1 & 1.000 & 1.053 & .000 & .1 .120 \\
\hline Pet & -127.013 & 306188.74 & .000 & 1 & 1.000 & .000 & .000 & 0.000 . \\
\hline Pdw & 2.979 & 2108.151 & .000 & 1 & .999 & 19.669 & .000 & 1.889. \\
\hline Vit B12 & .038 & 47.896 & .000 & 1 & .999 & 1.038 & .000 & 1.431 \\
\hline Constant & -27.175 & 38970.418 & .000 & 1 & .999 & .000 & & \\
\hline
\end{tabular}

ITP: Immune thrombocytopenia, Plt: Platelet, MPV: Mean platelet volume, Pct: Plateletcrit, PDW: Platelet disturbution width, B: Beta coefficient, CI: Confience interval, SE: Standard error, df: degree of freedom, Exp (B): exponentiation of B coefficient

\section{Discussion}

It is important to identify PTCP in order to avoid unnecessary diagnostic testing and treatment of healthy individuals. During evaluation of patients with thrombocytopenia, the first differential diagnosis to be excluded must be PTCP. Differential diagnosis is more difficult in primary care and centers that do not have a hematology department and cannot perform PB smear examination. In addition, there is still no distinctive demographic or blood marker for the diagnosis that is easily available. To date, few studies have investigated the associated clinical parameters. The determination of an association of demographic characteristics and underlying diseases with PTCP may help clinicians. Generally the phenomenon has been reported to be not age or gender-related $(3,11)$. However, Xiao Y et al. showed that the prevalence of EDTA- PTCP increases with age and a cohort aged $>50$ years included more males than females (12). In contrast, another study showed female predominace (13). In the current study, although the PTCP patients were older than both the ITP and control groups, the difference was not statistically significant. In addition, the number of comorbidities and co-existing autoimmune diseases were more frequent in PTCP patients. A previous report suggested that 
EDTA-PTCP occurs more frequently in severely ill patients with autoimmune, neoplastic, atherosclerosis-related, and liver diseases $(11,13)$, whereas other studies have reported no association with age, gender, burns, trauma, sepsis, human immunodeficiency virus, rubella, cytomegalovirus, autoimmune disorders, malignancy, cardiac surgery, or medication $(3,11,14)$.

In a study including 104 EDTA-PTCP patients and 208 matched control subjects, EDTA-PTCP patients were seen to have a higher frequency of malignant tumor and a lower frequency of HT and DM than the control group. It is interesting that they also somehow showed that the prognosis of EDTA-PTCP patients was significantly poorer compared to the control group (1). In the current study, the most common underlying diseases were HT, DM and hypo-hyperthyroidism. Moreover, 7\% of PTCP patients had underlying solid organ tumors and $22 \%$ had at least one autoimmuneassociated disease. As the healthy control group was selected from patients without any underlying disease, the effect of comorbidity on the prevalence of PTCP could not be analyzed. Similarly, Isik et al. showed that $23.8 \%$ of PTCP patients had DM, 32.5\% had HT, 26.3\% had atherosclerotic heart disease, and 10\% had hypothyroidism. There was no statistically significant difference between the control and patient groups in respect of comorbidities (11). All these results show that PTCP patients have chronic comorbidities especially autoimmunerelated disorders. As the most well-known underlying mechanism is immune-mediated anti-Plt autoantibodies $(6,7,11)$, it can be expected to coexist with immune-mediated disorders. However, no significant association or risk factor has yet been demonstrated.

The easily available blood parameters which may help clinicians to differentiate PTCP from other thrombocytopenic patients should be identified. Whether or not CBC parameters, especially plt indices, can be distinctive has been the subject of investigation. Studies published in the past few years have revealed that MPV may play an important role in the development, progression and complications of several human disorders (15). PTCP phenomenon has been shown to be associated with substantial and time-dependent changes of MPV. EDTA also generates a time-dependent shape change, swelling and increase of platelet size, so that the MPV measured in citrated blood can differ from that assessed in EDTA blood of the same donor (15). In contrast, in a study where the MPV on admission and at the time of diagnosis of EDTA-PTCP was analyzed, the authors showed that the mean MPV at the time of diagnosis of PTCP was 7.5 (range 6.5-8.3), which was not significantly altered from values prior to diagnosis (13). In the current study, the median MPV of PTCP patients was 9.4 [6.614.8] which was statistically higher than that of the ITP and heathy control groups. The Pct and Pdw values were also higher in the PTCP group. In another similar study, high white blood cell and MPV values were found in the PTCP group (11). According to all these results, higher MPV in a thrombocytopenic patient without bleeding history should arouse suspicion of PTCP. Another new study study investigated the use of MPV for distinguishing the causes of thrombocytopenia in adult patients (16). The authors suggested that MPV is useful for differentiating the cause of thrombocytopenia and MPV $\geq 8.8 \mathrm{fL}$ has acceptable sensitivity and specificity for diagnosis of over-destructive thrombocytopenia. In that study, underproductive bone marrow group comprised mostly patients with hematological malignancies whereas over-destructive thrombocytopenia group included only ITP patients. In addition to this data, although it is not a true thrombocytopenic situation, we found the PCTP patients had higher MPV levels than ITP patients in our study.

Xiao $\mathrm{Y}$ et al. analyzed the prevalence and biochemical profiles of EDTA-PTCP in a generally healthy population (12). EDTA-PTCP patients were compared with age and gendermatched randomly selected non-PTCP control subjects. The levels of alanine transaminase (ALT), aspartate transaminase (AST), alkaline phosphatase (ALP), lactate dehydrogenase (LDH), and uric acid were found to be significantly higher in the PTCP group. In the current study, the AST level of PTCP patients was higher than that of the ITP group but was similar to the values of the healthy control group. There were no other significant biochemical parameters distinctive for PTCP patients.

Logistic regression analysis, including all $\mathrm{CBC}$ and biochemical parameters which 
were found to be different in the PTCP group compared to the ITP and healthy control groups, revealed no significant association. At this point, the importance of microscopic examination of PB smear must be again emphasized. When EDTA-dependent PTCP is suspected, a blood sample of the patient with tubes containing other anticoagulants can be reevaluated (17). However, this simple and inexpensive diagnostic method is not always available in all centers. In such a situation, the clinician must suspect PTCP from the clinical and blood parameters and refer the patient to an advanced center. The major limitation of this study is the retrospective and descriptive design. The diagnosis of EDTA-PTCP in the current cases were not proved by the examination of blood samples with other anticoagulants such as heparin and citrate since we know that pseudothrombocytopenia may occur due to those anticoagulants. Further largescale, prospective, randomized clinical trials are needed to determine if any blood parameter is effective in differential diagnosis in patients with thrombocytopenia, especially in respect of PTCP.

In conclusion, EDTA-PTCP should be suspected in patients with low plt counts with no apparent bleeding tendency. Although the prevalence of EDTA-PTCP is low in the general population, it is often misdiagnosed and frequently may lead to unnecessary evaluations and treatment. Therefore, it is essential that all physicians are aware of this entity. Although some hematological and biochemical parameters may be used to suspect PTCP in cases of thrombocytopenia, microscopic PB smear analysis is still the most reliable and distinctive method.

\section{REFERENCES}

1. Ohashi-Fukuda $\mathrm{N}$, Inokuchi $\mathrm{R}$, Sato $\mathrm{H}$, Nakamura K, Iwagami M, Wada T, et al. Poorer prognosis with ethylenediaminetetraacetic acid-dependent pseudothrombocytopenia: a single-center case-control study. Medicine. 2015;94(15):e674.

2. Lin J, Luo Y, Yao S, Yan M, Li J, Ouyang W, et al. Discovery and Correction of Spurious Low Platelet Counts due to EDTA-Dependent Pseudothrombocytopenia. Journal of clinical laboratory analysis. 2015;29(5):419-26.

$3 . \quad$ Bizzaro N. EDTA-dependent pseudothrombocytopenia: a clinical and epidemiological study of 112 cases, with 10-year follow-up. American journal of hematology. 1995;50(2):103-9.
4. Sweeney JD, Holme S, Heaton WA, Campbell D, Bowen ML. Pseudothrombocytopenia in plateletpheresis donors. Transfusion. 1995;35(1):46-9.

5. Gowland E, Kay HE, Spillman JC, Williamson JR. Agglutination of platelets by a serum factor in the presence of EDTA. Journal of clinical pathology. 1969;22(4):460-4.

6. Chae H, Kim M, Lim J, Oh EJ, Kim Y, Han K. Novel method to dissociate platelet clumps in EDTAdependent pseudothrombocytopenia based on the pathophysiological mechanism. Clinical chemistry and laboratory medicine. 2012;50(8):1387-91.

7. Pegels JG, Bruynes EC, Engelfriet CP, von dem Borne AE. Pseudothrombocytopenia: an immunologic study on platelet antibodies dependent on ethylene diamine tetra-acetate. Blood. 1982;59(1):157-61.

8. Sakurai S, Shiojima I, Tanigawa T, Nakahara K. Aminoglycosides prevent and dissociate the aggregation of platelets in patients with EDTA-dependent pseudothrombocytopenia. British journal of haematology. 1997;99(4):817-23.

9. Howard L, Shulman S, Sadanandan S, Karpatkin S. Crossed immunoelectrophoresis of human platelet membranes. The major antigen consists of a complex of glycoproteins, GPIIb and GPIIIa, held together by $\mathrm{Ca} 2+$ and missing in Glanzmann's thrombasthenia. The Journal of biological chemistry. 1982;257(14):8331-6.

10. Kunicki TJ, Pidard D, Rosa JP, Nurden AT. The formation of $\mathrm{Ca}++-d e p e n d e n t$ complexes of platelet membrane glycoproteins IIb and IIIa in solution as determined by crossed immunoelectrophoresis. Blood. 1981;58(2):268-78.

11. Isik A, Balcik OS, Akdeniz D, Cipil H, Uysal S, Kosar A. Relationship between some clinical situations, autoantibodies, and pseudothrombocytopenia. Clinical and applied thrombosis/hemostasis : official journal of the International Academy of Clinical and Applied Thrombosis/Hemostasis. 2012;18(6):645-9.

12. Xiao Y, Yu S, Xu Y. The Prevalence and Biochemical Profiles of EDTA-Dependent Pseudothrombocytopenia in a Generally Healthy Population. Acta haematologica. 2015;134(3):177-80.

13. Berkman N, Michaeli Y, Or R, Eldor A. EDTAdependent pseudothrombocytopenia: a clinical study of 18 patients and a review of the literature. American journal of hematology. 1991;36(3):195-201.

14. Allerheiligen D, Houston R, Vermedahl B. EDTA-induced pseudothrombocytopenia. The Journal of the American Board of Family Practice. 1996;9(3):212-4. 15. Lippi G, Franchini M. Platelets and immunity: the interplay of mean platelet volume in health and disease. Expert review of hematology. 2015;8(5):555-7.

16. Norrasethada L, Khumpoo W, Rattarittamrong E, Rattanathammethee $\mathrm{T}$, Chai-Adisaksopha $\mathrm{C}$, Tantiworawit A. The use of mean platelet volume for distinguishing the causes of thrombocytopenia in adult patients. Hematology reports. 2019;11(1):7732.

17. Fang C-H, Chien Y-L, Yang L-M, Lu W-J, Lin M-F. EDTA-dependent pseudothrombocytopenia. Formosan Journal of Surgery. 2015;48(3):107-9. 